\title{
Morphological Variations in Tamarindus indica LINN. Fruits and Seed Traits in the Different Agroecological Zones of Uganda
}

\author{
Jaspher Okello $\mathbb{D}^{1},{ }^{1}$ John Bosco Lamoris Okullo, ${ }^{2}$ Gerald Eilu, ${ }^{2}$ \\ Philip Nyeko, ${ }^{2}$ and Joseph Obua ${ }^{2}$ \\ ${ }^{1}$ National Agricultural Research Organisation, P.O. Box 295, Entebbe, Uganda \\ ${ }^{2}$ School of Forestry, Environmental and Geographical Sciences, Makerere University, P.O. Box 7062, Kampala, Uganda \\ Correspondence should be addressed to Jaspher Okello; jaspherokello2016@gmail.com
}

Received 29 August 2018; Accepted 25 November 2018; Published 11 December 2018

Academic Editor: Daniel I. Rubenstein

Copyright (C) 2018 Jaspher Okello et al. This is an open access article distributed under the Creative Commons Attribution License, which permits unrestricted use, distribution, and reproduction in any medium, provided the original work is properly cited.

An investigation was carried out on variations in the morphological traits of Tamarindus indica LINN. fruits (length, breadth, mass, and pulp mass) and seeds (number and mass) from the different agroecological zones and land use types of Uganda. Fruits were collected from the two land use types in the three agroecological zones and measured for various morphological traits. The study sites were located between 593 and 1,096 meters above sea level. ANOVA was used to test the differences in morphological traits of fruits and seeds between agroecological zones and land use types. The morphological traits relationship was determined using Pearson Correlation Coefficient $(\mathrm{R})$. There were significant $(\mathrm{P} \leq 0.05)$ variations among the T. indica fruits and seed morphological traits within the agroecological zones and land use types. Lake Victoria Crescent agroecological zone recorded higher fruits morphological traits values. Wild and on-farm land use types were superior in fruits and seed traits, respectively. Many seeds per fruit (17) were recorded in Uganda (Eastern agroecological zone) than those recorded elsewhere. Significant uphill positive linear correlations between all morphological traits $(\mathrm{P} \leq 0.05)$ were observed, with the strongest relationships being between seed mass and seed number $(\mathrm{R}=0.79)$, fruit mass and fruit length $(\mathrm{R}=0.75)$, pulp mass and fruit mass $(\mathrm{R}=0.73)$, and seed mass and fruit mass $(\mathrm{R}=0.73)$. However, fruit breadth presented slightly weaker positive linear correlations with all other morphological traits. This is the first quantitative evaluation of T. indica morphological traits variation in Uganda. Dispersion/variation and correlation relationships suggest that all the studied morphological traits can be used for selection of plus trees for tree breeding improvement such as yield per tree. The observed variations are probably attributed to influence of agroecological zones' factors, environmental factors, climate, land use types, and farming systems, a reflection of $T$. indica adaptation to different conditions showing high genetic and phenotypic differences to be exploited.

\section{Introduction}

Tamarindus indica LINN. (Linnaeus 1753) is a fruit tree species that belongs to the Order FABALES, family FABACEAE syn. LEGUMINACEAE, subfamily CAESALPINIOIDEAE, and Genus TAMARINDUS. The genus Tamarindus is monotypic, containing a single species, Tamarindus indica [1]. Commonly, Tamarindus indica is known by the following local names: English names (Madeira mahogany, Indian date, and tamarind); trade name (tamarind); Ateso, Eastern Uganda (Epeduru); Luo, Northern Uganda (cwao); Luganda, Lake Victoria Crescent zone (mukoge), as well as Lugbara and Madi dialects of West Nile (Iti) in Uganda.
The T. indica tree is widespread throughout the tropics and subtropics. It originated from tropical Africa [2] and native to many tropical African countries including Uganda, where it naturally dominates six out of nine agroecological zones. The fruit tree is naturally widespread on-farms and in the wild habitats in the tropics [1] as well as in Uganda [3] and grows well over a wide range of soil and climatic conditions, ranging from low altitude woodland savanna of about 590 masl (lowest point in Uganda at Albert Nile) to high altitude Mt. Elgon ranges of above 2,000 masl [4].

The ecological range of $T$. indica is very wide, corresponding to the polymorphous character of the species. According to Okello et al. [3-5], the species is frequently associated 
with shrubs, deciduous thickets, termite mounds, agricultural landscapes, abandoned homesteads (settlements), and public places. While El-Siddig et al. [1] reported that the T. indica fruits from different regions of Sudan are morphologically different, Gebauer et al. [6] reported that in some regions of Sudan, $T$. indica fruits are sweeter than others. The variations in size, shape, flavor, and colour of fruits and seeds have also been reported in many other studies elsewhere [79]. The multipurpose long-lived fruit tree that supports the livelihoods of many poor rural communities is useful for meeting cultural, social, economic, ecological, and many other significant needs [4]. The species provides households' food security, timber, nutritional needs, and treatment and prevention of diseases (meningitis, fever, cough, intestinal disorders) and combine well with cereal and perennial crops on-farms. In on-farms, T. indica provides shade for human, animals, and crops; ornamental and avenue tree; windbreak or shelterbelt; soil fertility improvement (mulch and $\mathrm{N}$ fixation), animal fodder in zero grazing systems, and energy needs (firewood and charcoal).

The $T$. indica can serve as good natural and cheap sources of macro and trace minerals, proximate and physiochemical composition. Its seeds contain more minerals (especially $\mathrm{Zn}$, $\mathrm{Fe}, \mathrm{Mg}, \mathrm{P}, \mathrm{Na}$, and $\mathrm{Ca}$ ), crude oil, carbohydrates, calorific values, acid, and peroxide values than the pulp. While the pulp contains more proximate properties (moisture content, total ash, and crude protein), ascorbic acid, and $\mathrm{K}$ than the seeds [3-5]. However, Uganda has not yet developed the $T$. indica agroprocessing industries that would provide the ready-made products for locally available markets and exports. The native tree legume species has been neglected and indiscriminately grows without much attention in many places like on-farm, wild, roadsides, riverine, market places, and mountainous areas. The study of morphological traits of natural populations is often considered to be useful step in the study of the genetic variability [10]. Morphological characteristics information of $T$. indica is also useful in determining the domestication, protection, consumption, commercialization, and development of local industries. Additionally, morphological variability also signifies the adaptation of the species to the environment and it may be genetically or environmentally determined [8].

Until recently when $T$. indica species was prioritized for conservation and product development to support livelihoods in sub-Saharan Africa and other African countries, T. indica utilisations have depended largely upon wild populations, with no conservation strategies [11]. The wild habitats are threatened by anthropogenic activities such as charcoal burning for household incomes, food and firewood gathering, effects of wild fires, construction materials, animal fodder and increasing conversion to farmlands that have led to serious species genetic erosion. Much as several studies were carried out on Uganda's T. indica species [3-5, 1214], there is still inadequate scientific information on fruits and seed morphological traits' relationships between agroecological zones and land use types. When made available, such information can guide the selection of $T$. indica tree species for various uses and breeding improvement. This study therefore aimed at evaluating the variations of $T$. indica fruits and seeds' morphological traits between the different agroecological zones and land use types in Uganda. It was, thus, hypothesised that there were no significant differences in the morphological traits of T. indica fruits and seeds across the agroecological zones of Uganda.

\section{Materials and Methods}

2.1. Description of Agroecological Zones of Uganda. Uganda, officially known as the Republic of Uganda, is located in the East African region on the edge of the Equator. It occupies total area of $241,038 \mathrm{~km}^{2}$, averages about 1,100 meters above sea level, and lies between latitude $1^{\circ} 30^{\prime} \mathrm{N}$ and $32^{\circ} 00^{\prime} \mathrm{E}$. Uganda's geographical features comprise plateaus, highlands, mountains, rolling hills, flat lands, rivers, lakes, and wetlands. The climate is tropical and generally rainy with defined two dry seasons. The predominant rocks were formed between 3,000 and 6,000 million years ago (pre-Cambrian era). However, in some western and eastern parts of the country, there are major developments of younger rocks, which are either sediments or volcanic in origin ranging from 135 million years ago (cretaceous period) to the present day [15]. The type and character of the soils of Uganda are defined by a number of parameters such as the nature of the parent rock, age of the form, and climate, especially the amount of moisture.

The country is divided into nine different agroecological zones, based on agroclimatic factors (rainfall totals and distribution) and soils (productivity and fertility). Topography, temperatures, moisture, and vegetation cover are the secondary factors considered to be uniform in each agroecological zone but differs between zones [16]. The wet and dry seasons are fairly marked with dry season between late November and March. The present study on T. indica was conducted in the three different agroecological zones of Uganda where T. indica trees are grown both on-farms and in the wild. Each of the selected agroecological zone was represented by a district (Figure 1). In addition, the sampled agroecological regions represented by Moyo, Nakasongola, and Soroti districts are more than 200 kilometres apart, to avoid having the same offspring and having the effects of agroecological zones' factors.

2.2. Description of the Study Areas. The study was carried out in three agroecological zones of Uganda, namely, West Nile, Lake Victoria Crescent, and Eastern out of the nine agroecological zones. Each selected agroecological zone was represented by the district of Moyo, Nakasongola, and Soroti, respectively. Attributes of each study area (district) within the agroecological zone are summarised in Table 1.

2.3. Sampling Design. The sampling sites from each of the agroecological zones were chosen from over $200 \mathrm{~km}$ apart that took into consideration ecological factors of the area, influence of climate or environmental factors and farming systems [4]. The agroecological zones are also separated by major physical features such as water bodies. Each zone was stratified into two major land use types: onfarm (current crop fields) and wild lands or fallow fields. 


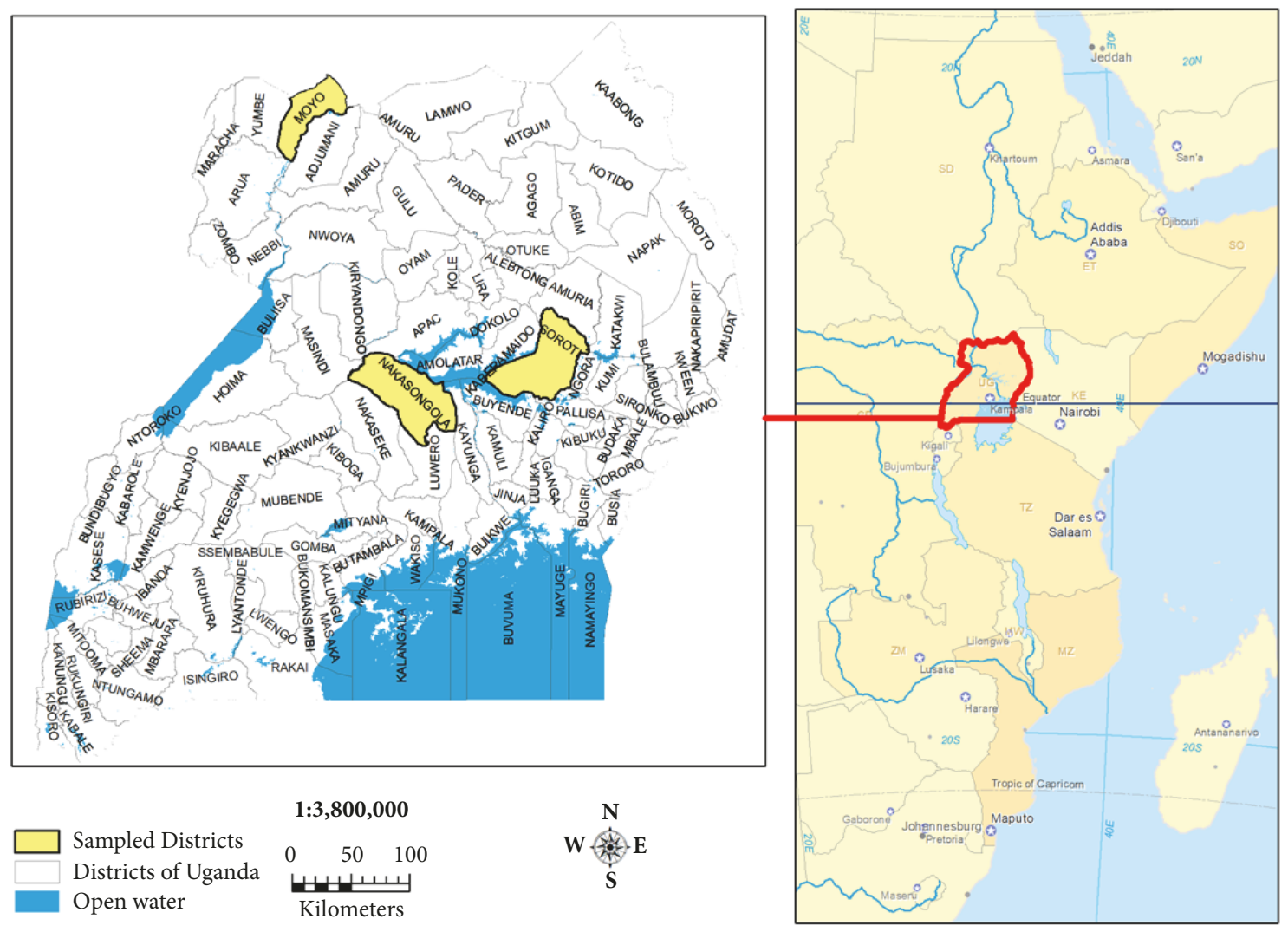

FIGURE 1: Map of Uganda showing sample sites in different agroecological zones.

The on-farm lands are current farm lands for agricultural crops (annual or perennial) while the wild or fallow fields have not been cultivated for five or more years prior to this study. Three agroecological zones were selected based on the large naturally occurring population of $T$. indica. Each agroecological zone was represented by a district-an administrative unit comprising of many subcounties. In each district, four subcounties were randomly selected, thus making four subcounties per district (zone). In each selected subcounty, five $T$. indica trees were selected from each of the two land use types, thus a total of twenty mature trees were selected from each land use type in each zone (district). Selected trees were separated from each other by more than 200 meters apart to minimize the risk of sampling closely related individuals (siblings). Selection criteria included ease of access, well developed crowns, good tree health (absence of obvious signs of pests, diseases, and fire disturbances), and presence of good-looking fruits [3].

2.4. Data Collection. The T. indica fruits were collected during the 2007 fruiting season from December 2007 to March 2008. The canopy of each sample tree was divided into three levels (top, middle, and bottom). The trees were climbed using ladders to collect ripe fruits which were selected by gently squeezing to check if ready. Ripe fruits were considered to be those with scurfy brown, woody, fragile shell with brown pulp and blackish-brown, and hard shiny seeds [3]. Eight fruits were randomly collected from each canopy level (two from each of the cardinal compass directions). In total, 24 fruits were harvested from each tree. A total of 480 fruits were, therefore, harvested from 20 trees per land use type, giving 960 fruits per agroecological zone (represented by district) and 2,880 fruits for the two land types in each agroecological zone. The fruits collected from each sampled tree, land use, and agroecological zone were bagged and labelled to avoid loss of tree identity and assessed for fruit physical characterization. Each sampled tree was labelled and its location recorded using a Global Position System (GPS) unit to determine its altitude. Fruits collected from each tree were pooled, kept in white polythene bags, and labelled according to tree number and canopy levels, for example, $\mathrm{T}_{1} \mathrm{C}_{1}, \mathrm{~T}_{1} \mathrm{C}_{2}$, and $\mathrm{T}_{1} \mathrm{C}_{3}$ (representing tree number and tree canopy number). The fruits were allowed to dry at room temperature for five days before storing them in polythene bags. The bags were labelled with a permanent marker for ease of identification. The fruits were then taken to Makerere University's College of Agricultural and Environmental Sciences laboratory where they were stored in cool and dry place for further processing.

2.5. Quantitative Trait Measurements. All fruits collected were washed with distilled water to remove foreign particles and other inert materials and allowed to dry in the sun for about one hour. After this, the following descriptive 
TABLE 1: Summary of study areas.

\begin{tabular}{|c|c|c|c|}
\hline \multirow{2}{*}{$\begin{array}{l}\text { Attributes } \\
\text { Agroecological zone }\end{array}$} & \multicolumn{3}{|c|}{ Details of Studied District Representing Agro-ecological Zones } \\
\hline & West Nile & Lake Victoria Crescent & Eastern \\
\hline District & Moyo & Nakasongola & Soroti \\
\hline Location & $03^{\circ} 39 \mathrm{~N} 31^{\circ} 43^{\prime} \mathrm{E}$ & $01^{\circ} 18^{\prime} \mathrm{N} 32^{\circ} 30^{\prime} \mathrm{E}$ & $01^{\circ} 43^{\prime} \mathrm{N} 33^{\circ} 36^{\prime} \mathrm{E}$ \\
\hline Geographical location & North Western Uganda & Central Uganda & Eastern Uganda \\
\hline Land area $\left(\mathrm{km}^{2}\right)$ & 2,059 & 3,512 & 2,663 \\
\hline Altitude (masl) & $900-1,500$ & $1,000-1,400$ & $1,036-1,127$ \\
\hline History & District formed in 1956 & District created in 1997 & District formed in 1962 \\
\hline $\begin{array}{l}\text { Major geological } \\
\text { formations }\end{array}$ & $\begin{array}{l}\text { Gneiss, alluvial deposits, \& } \\
\text { schist, quartzite \& marble }\end{array}$ & $\begin{array}{l}\text { Buganda-Toro System geological } \\
\text { formation }\end{array}$ & $\begin{array}{l}\text { Granites, mignalites, gneiss, } \\
\text { schists and quartzites }\end{array}$ \\
\hline Major soil types & $\begin{array}{l}\text { Vertisols, Leptosols, alluvial } \\
\text { deposits \& Ferralsols }\end{array}$ & $\begin{array}{l}\text { Bululi and Lwampanga soil } \\
\text { catena }\end{array}$ & $\begin{array}{l}\text { Serere and Amuria catena, Metu } \\
\text { complex and Usuk series }\end{array}$ \\
\hline Economic activities & Subsistence agriculture & $\begin{array}{l}\text { Livestock and subsistence } \\
\text { agriculture }\end{array}$ & Subsistence agriculture \\
\hline Rainfall $(\mathrm{mm})$ & $1,500-1,700$ & $600-1,000$ & $1,000-1,500$ \\
\hline \multirow{2}{*}{ Rainfall patterns } & March-June; & March-July; & March - June; \\
\hline & August-November & August-November & August - November \\
\hline Dry season & Late November to early March & Late November to early March & December to February \\
\hline Min. and max. temp. & $23.7^{\circ} \mathrm{C}$ and $30^{\circ} \mathrm{C}$ & $18^{\circ} \mathrm{C}$ and $35^{\circ} \mathrm{C}$ & 18 and $31.3^{\circ} \mathrm{C}$ \\
\hline Climate & Modified equatorial & Tropical type & Tropical savanna \\
\hline Historical sites & $\begin{array}{l}\text { Limestone burning hole at Arapi, } \\
\text { Metu tourist attraction cave, Mt. } \\
\text { Otze, Kotilo Sacred Forest, Emin } \\
\text { Pasha's underground Fort at } \\
\text { Dufile, Era Forest, Moki and } \\
\text { Metu springs, Albert Nile }\end{array}$ & $\begin{array}{l}\text { White rhinoceroses' sanctuary, } \\
\text { bird watching, Nakasongola hills }\end{array}$ & $\begin{array}{l}\text { Soroti rock, East African Civil } \\
\text { Aviation Academy, Lake Bisina, } \\
\text { Namulekwa island, Mulondo and } \\
\text { Mugarama landing sites, } \\
\text { Bugondo and Ogera hills, } \\
\text { Omeleku rocks, Agu swamp } \\
\end{array}$ \\
\hline
\end{tabular}

Source: $[3-5,17-20]$.

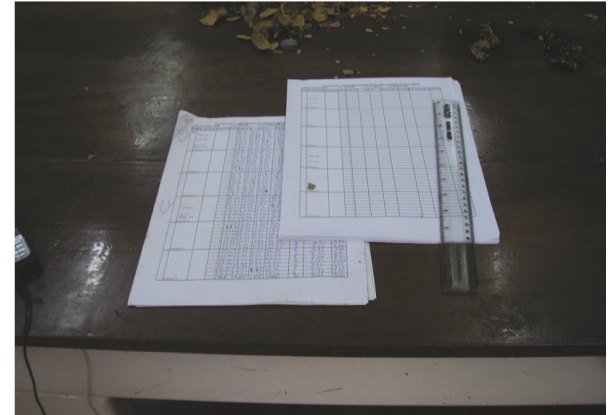

FIGURE 2: Morphological triplicate measurements.

parameters were determined in triplicate and the average was determined: fruit length $(\mathrm{cm})$, fruit breadth $(\mathrm{cm})$, individual fruit total mass $(\mathrm{g})$, total seeds mass $(\mathrm{g})$, total pulp mass $(\mathrm{g})$, and number of seeds per fruit (Figure 2). Length of fruit was determined as the distance from the panicle to the end of fruit on the outer surface (measured with the help of a thread and meter ruler). Measurements for curved fruits were made on the outer side of the curve. Fruit breadth was determined by using a vernier calliper graduated in $0.1 \mathrm{~cm}$. Pulp mass was obtained by weighing the pulp per fruit using an electric weighing scale to $100 \%$ accuracy and

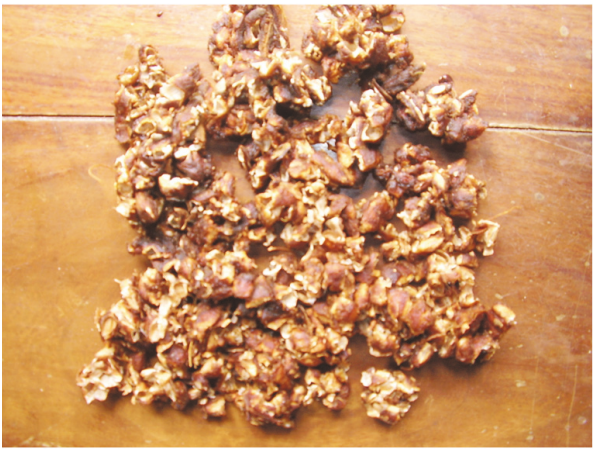

FIGURE 3: Assorted clean pulp for analysis.

graduated to 2 decimal places $(0.00 \mathrm{~g})$ after removing the seeds. Depulping of fruits was done using a pair of scissors. Total seed mass and number of filled (sound) seeds per fruit were determined in accordance with procedures of ISTA [20]. To determine seed mass, seeds were manually removed from the fruits (depulped), counted to determine the numbers per fruit, later weighed in triplicate, and recorded. Decomposing fruits, pulp, and seeds damaged by insects and other objects were excluded from the samples after measurement to avoid contamination of whole samples (Figure 3). 
TABLE 2: T. indica fruits and seeds morphological/quantitative traits.

\begin{tabular}{|c|c|c|c|c|c|c|c|}
\hline \multirow{2}{*}{ Morphology Traits } & \multirow{2}{*}{ Unit } & \multirow{2}{*}{ Measures } & \multicolumn{3}{|c|}{ Three Agro-ecological Zones } & \multicolumn{2}{|c|}{ Land Use Types } \\
\hline & & & Lake Victoria C. & Eastern & West Nile & Wild & On-farm \\
\hline \multirow{2}{*}{ Fruit length } & \multirow{2}{*}{$(\mathrm{cm})$} & $\operatorname{Min}-\operatorname{Max}$ & $4.30-29.80$ & $4.20-22.50$ & $4.30-24.10$ & & \\
\hline & & Mean \pm SD & $11.73 \pm 3.3^{\mathrm{a}}$ & $10.67 \pm 2.9^{\mathrm{b}}$ & $12.48 \pm 2.9^{c}$ & $12.00 \pm 0.51^{\mathrm{a}}$ & $11.40 \pm 0.45^{\mathrm{b}}$ \\
\hline \multirow{2}{*}{ Fruit breadth } & \multirow{2}{*}{$(\mathrm{cm})$} & Min - Max & $1.10-3.00$ & $1.20-2.60$ & $1.30-2.70$ & & \\
\hline & & Mean \pm SD & $1.98 \pm 0.3^{\mathrm{a}}$ & $1.76 \pm 0.3^{\mathrm{b}}$ & $1.87 \pm 2.0^{c}$ & $1.90 \pm 0.21^{\mathrm{a}}$ & $1.80 \pm 0.05^{\mathrm{b}}$ \\
\hline \multirow{2}{*}{ Fruit mass } & \multirow{2}{*}{$(\mathrm{g})$} & Min - Max & $1.40-56.80$ & $2.40-45.60$ & $2.00-32.50$ & & \\
\hline & & Mean \pm SD & $14.30 \pm 7.4^{\mathrm{a}}$ & $13.40 \pm 6.1^{\mathrm{b}}$ & $13.17 \pm 5.3^{\mathrm{b}}$ & $13.80 \pm 0.49^{\mathrm{a}}$ & $13.60 \pm 0.86^{\circ}$ \\
\hline \multirow{2}{*}{ Pulp mass } & \multirow{2}{*}{ (g) } & Min - Max & $0.19-22.00$ & $0.94-19.30$ & $0.27-15.80$ & & \\
\hline & & Mean \pm SD & $4.58 \pm 2.8^{\mathrm{a}}$ & $5.25 \pm 2.8^{\mathrm{b}}$ & $5.24 \pm 2.4^{\mathrm{b}}$ & $5.20 \pm 0.36^{\mathrm{a}}$ & $4.90 \pm 0.15^{\mathrm{b}}$ \\
\hline \multirow{2}{*}{ Total seed No. } & \multirow{2}{*}{$\#$} & Min - Max & $1-15$ & $1-17$ & $1-14$ & & \\
\hline & & Mean \pm SD & $5.59 \pm 2.8^{\mathrm{a}}$ & $5.84 \pm 2.7^{\mathrm{b}}$ & $6.53 \pm 2.8^{c}$ & $5.90 \pm 0.59^{\mathrm{a}}$ & $6.10 \pm 0.67^{\mathrm{a}}$ \\
\hline \multirow{2}{*}{ Total seeds mass per fruit } & \multirow{2}{*}{ (g) } & Min - Max & $0.18-17.15$ & $0.19-11.93$ & $0.20-12.20$ & & \\
\hline & & Mean \pm SD & $4.22 \pm 2.5^{\mathrm{a}}$ & $3.36 \pm 1.9^{\mathrm{b}}$ & $3.88 \pm 2.1^{\mathrm{c}}$ & $3.80 \pm 0.15^{\mathrm{a}}$ & $3.90 \pm 0.27^{\mathrm{a}}$ \\
\hline
\end{tabular}

Same superscript letters in each row are not statistically significant according to LSD test at $\mathrm{P} \leq 0.05$.

2.6. Data Analysis. Each of the fruit and seed samples was aggregated by land use type and agroecological zone. Analyses were carried out in triplicate to investigate relationships between agroecological zones and land use types. Two-Way Analysis of Variance (ANOVA) (with agroecological zone and land use types as fixed factors) was used to analyse the data using IBM statistic version 16.0. The Least Significant Difference (LSD) in a Post Hoc Test was used to separate means at 5\% using the General Linear Model (GLM) for Post Hoc Multiple Comparisons of Observed Means. Pearson Correlation Coefficient (R) was calculated to determine the relationship among the morphological characteristics in T. indica fruits and seeds. Additionally, the morphological traits dispersion/variability was calculated to describe the variability of the study population.

\section{Results}

3.1. Quantitative Variations of T. indica Fruits and Seed Morphological Traits. There were significant $(\mathrm{P} \leq 0.05)$ differences between agroecological zones and all morphological traits (Table 2). There were also significant differences in the $T$. indica morphological characteristics between land use types. The results indicate that West Nile agroecological zone had the longest mean fruits of $12.48 \pm 2.9$ but the maximum value $(22.50 \mathrm{~cm})$ was witnessed in the sample from Lake Victoria Crescent zone and higher mean seed numbers $(6.53 \pm 2.8)$ with the maximum number (17) being recorded in eastern zone. Lake Victoria Crescent zone had wider mean fruits (1.98 \pm 0.3$)$, heavier mean fruits $(14.30 \pm 7.4)$, and heavier mean seeds $(4.22 \pm 2.5)$, while Eastern zone had heavier mean pulp (5.25 \pm 2.8$)$. In addition, all the fruit trait values were higher in the wild land use type compared to all seed traits that recorded higher values in on-farm land use type (Table 2).

3.2. Morphological Traits, Agroecological Zones, and Land Use Types. The observed differences in values of T. indica fruits and seeds morphological characteristics between the land use

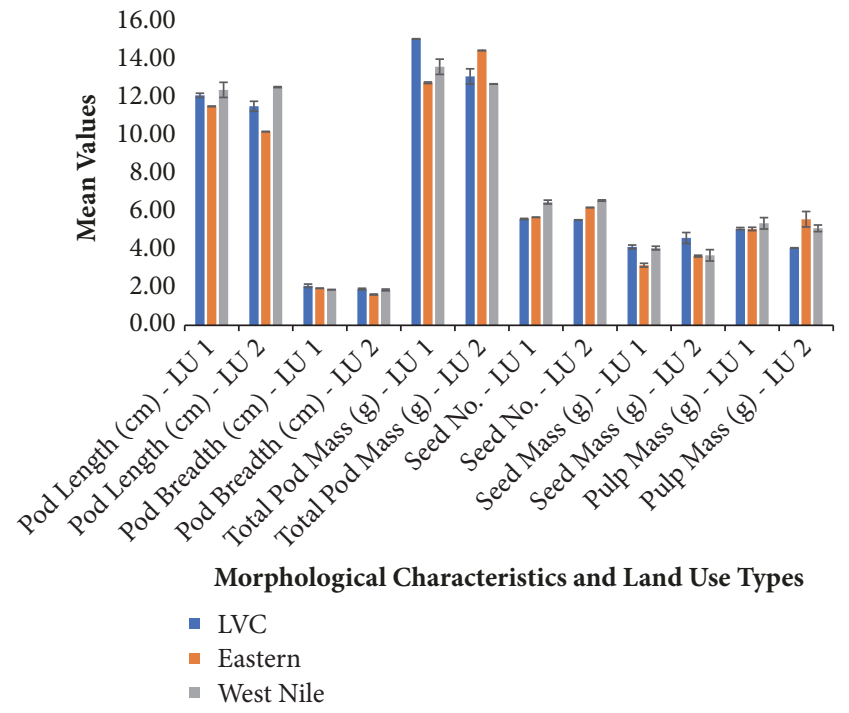

FIgURE 4: Variations of T. indica morphological characteristics by land use types. Key: LU 1, land use 1 (wild); LU 2, land use 2 (onfarm).

types and agroecological zones showed that most of T. indica samples from the Lake Victoria Crescent agroecological zone and wild land use type had higher morphological values compared to other zones and on-farm land use type. Only seed number consistently showed higher average values in West Nile than in Eastern and Lake Victoria Crescent agroecological zones, respectively (Figures 4 and 5).

3.3. Correlations Between T. indica Fruits and Seeds Morphological Traits. Table 3 shows the correlations $(\mathrm{P} \leq 0.05)$ between the $T$. indica fruits and seeds morphological traits. Strong uphill positive linear relationships were observed between seed mass and seed number $(\mathrm{R}=0.78)$, total fruit mass and fruit length $(\mathrm{R}=0.73)$, pulp mass and total fruit mass $(R=0.72)$, and seed mass and total fruit mass $(R=0.72)$. 
TABLE 3: Pearson coefficient (R) of correlation between T. indica morphological traits.

\begin{tabular}{|c|c|c|c|c|c|c|}
\hline Morphotypes & & Fruit Length & Fruit Breadth & Fruit Mass & Seed Number & Seed Mass \\
\hline \multirow{3}{*}{ Fruit Breadth } & Pearson Correlation & $0.480^{* *}$ & & & & \\
\hline & Sig. (2-tailed) & 0 & & & & \\
\hline & $\mathrm{N}$ & 2880 & & & & \\
\hline \multirow{3}{*}{ Fruit Mass } & Pearson Correlation & $0.749^{* *}$ & $0.491^{* *}$ & & & \\
\hline & Sig. (2-tailed) & 0 & 0 & & & \\
\hline & $\mathrm{N}$ & 2880 & 2880 & & & \\
\hline \multirow{3}{*}{ Seed Number } & Pearson Correlation & $0.580^{* *}$ & $0.222^{* *}$ & $0.626^{* *}$ & & \\
\hline & Sig. (2-tailed) & 0 & 0 & 0 & & \\
\hline & $\mathrm{N}$ & 2880 & 2880 & 2880 & & \\
\hline \multirow{3}{*}{ Seed Mass } & Pearson Correlation & $0.527^{* *}$ & $0.338^{* *}$ & $0.725^{* *}$ & $0.786^{* *}$ & \\
\hline & Sig. (2-tailed) & 0 & 0 & 0 & 0 & \\
\hline & $\mathrm{N}$ & 2880 & 2880 & 2880 & 2880 & \\
\hline \multirow{3}{*}{ Pulp Mass } & Pearson Correlation & $0.556^{* *}$ & $0.382^{* *}$ & $0.731^{* *}$ & $0.558^{* *}$ & $0.564^{* *}$ \\
\hline & Sig. (2-tailed) & 0 & 0 & 0 & 0 & 0 \\
\hline & $\mathrm{N}$ & 2880 & 2880 & 2880 & 2880 & 2880 \\
\hline
\end{tabular}

** Correlation is significant at $\mathrm{P} \leq 0.05$ level (2-tailed).

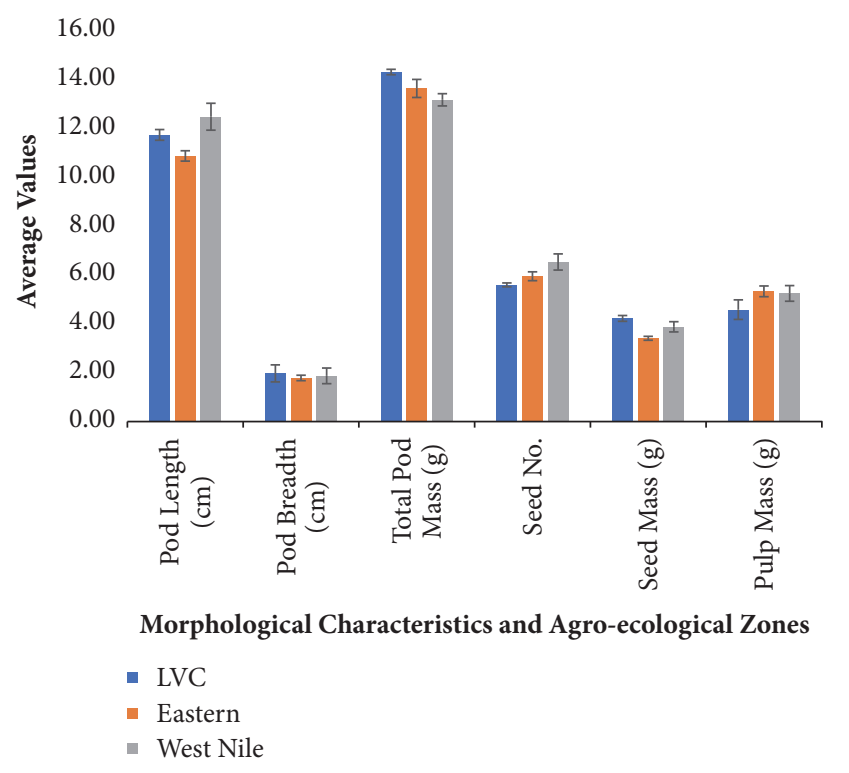

FIgURE 5: Variations of T. indica morphological characteristics by agroecological zones.

There were strong uphill positive relationships observed for seed number and fruit mass $(\mathrm{R}=0.63)$, seed number and fruit length $(\mathrm{R}=0.58)$, seed mass and fruit length $(\mathrm{R}=0.53)$, pulp mass and fruit length $(\mathrm{R}=0.56)$, pulp mass and seed mass $(R=0.56)$, fruit mass and fruit breadth $(R=0.49)$, fruit breadth and fruit length $(\mathrm{R}=0.48)$, pulp mass and fruit breadth $(\mathrm{R}=0.38)$, and seed mass and fruit breadth $(\mathrm{R}=0.34)$. A weak uphill positive linear relationship was observed for seed number and fruit breadth $(\mathrm{R}=0.22)$.

\section{Discussion}

\subsection{Quantitative Variations in T. indica Fruits and Seed Traits}

4.1.1. Fruits and Seed Traits Quantitative Variations. Statistical analyses indicate that most of the significant morphological variation occurs among the agroecological zones and land use types, although morphological variation is more significant in the agroecological zones than in the land use types. Many factors may have contributed to the divergence; for example, the reproductive and vegetative traits usually manifest different patterns of variations. Variations in $T$. indica fruit morphological traits have been reported by other authors [21-25]. Studies on fruits and seeds morphological traits in many tree species natural populations have also been reported by Okwu et al. [7]; Fatima et al. [8]; Mingfei et al. [26]; Dadegnon et al. [27]; Mkwezalamba et al. [28]; and Abasse et al. [29]. In accordance with the findings of Mingfei et al. [26], it is certainly the case that many factors contribute to the relative amounts of variation observed among populations of the same species, particularly when populations have been separated for long period of time. The observed variations suggest that different factors affect morphological traits, at least in the different agroecological zones and land use types such as environmental and climatic factors.

Fruit length varied at $4.20-29.80 \mathrm{~cm}$, fruit breadth at 1.10 $3.00 \mathrm{~cm}$, fruit mass at $1.40-56.00 \mathrm{~g}$, pulp mass at $0.19-22.00 \mathrm{~g}$, total seed number at 1-17, and seed mass at $0.18-17.15 \mathrm{~g}$. It is evident from this study that the dispersion/variation observed in fruit traits-mass (22.13), length (10.11), and pulp mass (9.13) - was higher than the dispersion/variation observed in seed traits-number (6.44) and mass (6.40)-respectively. These differences reflect that fruit traits, especially fruit 
mass, integrate all other fruit and seed traits. This suggest that variations exist in $T$. indica fruit traits especially fruit mass, and these variations also cut across into the seed number-the longer the fruits, the more the fruit pulp and the likelihood of the fruit producing many seeds, or the shorter the fruits, the less the amount of fruit pulp and the more the likelihood of the fruit producing few seeds. Similar observations were documented [7] for C. albidum. The tree variation observed in all the traits studied is typical of that found in an outbreeding species and the trend appears to be consistent with fruits of a particular outbreeding species.

The observed variation can also be further emphasized by the strong uphill positive linear correlations observed between fruit mass and fruit length $(\mathrm{R}=0.75)$, pulp mass and fruit mass $(\mathrm{R}=0.73)$, and seed mass and seed number $(\mathrm{R}=0.79)$. The large variation in the fruit and seed traits suggests that there are considerable opportunities for phenotypic selection of the species for quantitative and qualitative improvement in productivity. These variations observed could be attributed to the different genetic, effects of environment and climatic factors as well as growing conditions of the tree species because all the agroecological zones were significantly different. The diversity among these attributes could potentially form the basis for future breeding programmes, thereby contributing significantly towards hunger alleviation, nutritional benefits, and income generation, in particular among the rural poor people of Uganda.

4.1.2. Fruit Length. Longer fruits $(4.30-29.80 \mathrm{~cm})$ were documented from Lake Victoria Crescent zone. These results show that fruit length values are within those obtained by Orwa et al. [30] but higher than values obtained for other species such as those by Mkwezalamba et al. [28], Orsanic et al. [31], and Jarret and Berke [32] for Sclerocarya birrea (A. Rich.), Sorbus torminalis L. Crantz, and Capsicum chinense Jacq., respectively. Orsanic et al. [31] found out that the higher the altitude of the tree population, the longer the fruits, which confirms the findings of this study that documented that Lake Victoria Crescent (1050-1093 masl) and Eastern (1030-1096 masl) zones are located at higher altitudes than West Nile (593-997 masl) zone. Abasse et al. [29] also reported that phenotypic variation in fruits and seeds may reflect natural selections related to rainfall gradient influence on adaptability of different fruit tree populations. The variation of $T$. indica fruit length shows that superior phenotype could be ideal candidates for multiplication in the event that bigger and longer fruits are preferred. Mayavel et al. [21] found out that it might be inferred that fruit length, breadth, weight, pulp weight, and other traits could be considered as most important yield contributing traits in red tamarind.

Many research works conducted with fruits and seeds of tree species from different botanical families, such as cucumber tree (Averrhoa bilimbi L.) of Oxalidaceae family [33], Campomanesia adamantium of Myrtaceae family [34], and majestic heaven lotus (Gustavia augusta L.) from Lecythidaceae family [35], indicate that longer and wider fruits usually present higher values of fruit mass and seeds. These authors' results are in total agreement with the results of our study which showed that longer, wider, and heavier fruits have more seeds. However, it is not clear whether the species with long and large T. indica fruits may be more productive than those with narrow and short fruits. The observed variations could probably be attributed to environmental and climatic factors, agroecological zones factors, and farming systems, which partly agrees with the work of Abasse et al. [29]. A positive and quite strong correlation between the fruit length and all studied traits obtained means that fruit length is important and determinant for all the traits studied in tree breeding programme. In cases where $T$. indica provenances with the longer and wider fruits can be selected, it would mean that more preferred products can be obtained in large quantities and T. indica trees that produce these fruits can be recommended for tree per yield improvement.

4.1.3. Fruit Breadth. The T. indica wider fruits $(1.10-3.00 \mathrm{~cm})$ were documented from Lake Victoria Crescent zone. Other authors such as Mkwezalamba et al. [28] and Orsanic et al. [31] documented values for Sclerocarya birrea (A. Rich.) Hochst. and Sorbus torminalis L. Crantz, respectively, which are within the results of our study. Meanwhile, higher values were documented for other species [29, 32] for Balanites aegyptiaca and Capsicum chinense Jacq., respectively. Fruit length and breadth are important morphological characteristics for plants characterization because biometric studies of fruits and seeds and their phenotypical correlations can allow the quantitative evaluation of a relevance character in relation to another [36]. The generated significant variations in fruit production between provenances is an indication that superior provenances of $T$. indica can be selected for domestication, breeding improvement, and commercialization purposes. This study found that fruit breadth is a least important trait for consideration to any tree breeding improvement. The findings concur with Orsanic et al. [31] who documented that when determining fruit shape, width seems to be a less important property than length.

4.1.4. Fruit Mass. T. indica samples from Lake Victoria Crescent zone recorded heavier fruits (1.40-56.80 g) while lighter fruits (2.00-32.50 g) were recorded from West Nile zone. Fruit size, thickness, shiny color, and shape are some important qualitative characteristics for consumer acceptability on the market. Our study documented lower values than those reported by Bilcke et al. [22]. Higher values were documented for other species [28, 29, 31, 32] for Sclerocarya birrea (A. Rich.), Balanites aegyptiaca, Sorbus torminalis L. Crantz, and Capsicum chinense Jacq., respectively. According to Imrak et al. [37], fruit and seed size are determined by the genetic characteristics of each cultivar and also influenced by plant management. Since fruit size is used for grading produce, large fruits would normally attract premium prices due to their greater capability to store photosynthates having a lower rate of respiration [38]. During fruit growth, fruit size usually increases, and such increase is determined by the cultivar and by cell elongation during anthesis and after anthesis [38].

The significant differences in fruit mass as found in this study are probably a result of genetic and environmental factors. Positive and strong correlations between the fruit 
mass and fruit length $(\mathrm{R}=0.75)$, pulp mass $(\mathrm{R}=0.73)$ and seed mass $(R=0.73)$, and fruit breadth $(R=0.49)$ and seed number $(\mathrm{R}=0.73)$ mean that larger and longer fruits should be collected as they give many and heavy seeds and heavier pulp. Our study findings show that T. indica fruit mass is the most important parameter for tree breeding improvement. Similar results were documented by Mayavel et al. [21] who found out that fruit mass is among the 15 characters taken into consideration for yield per tree improvement in red tamarind in Tamil Nadu.

4.1.5. Pulp Mass. Heavy pulp (0.10-22.00 g) and lighter pulp (0.27-15.80 g) were recorded in Lake Victoria Crescent and West Nile agroecological zones, respectively. It is clear from this study that $T$. indica produces pulp of different mass depending on the agroecological zone and land use types. This could probably be caused by agroecological zone, land use, genetic, phenotypic, environmental, and climatic factors. According to Mkwezalamba et al. [28], variations in fruit pulp weight usually depend on provenances. Mingfeli et al. [26] also reported that key environmental factors and genetic divergence can also coaffect the phenotypic variation in vegetative and reproductive traits which is an observed variation in T. indica. In general, both vegetative and reproductive traits may adapt to these responses differently with respect to local environment and climate.

The strong correlations documented between pulp mass and fruit mass imply that the bigger the fruit, the more the pulp mass of that given fruit. Since pulp is the single most important $T$. indica product which is variously used $[3,4]$, the $T$. indica industry in Uganda should first target the agroecological zone (such as the Lake Victoria Crescent) which produces bigger fruits for research and development. Such programme should focus on both on-farm and wild $T$. indica populations which have shown significant differences between these land use types. This variability can be important in selecting the best pulp mass for further research and multiplications instead of relying on natural regeneration that will continue producing similar offspring. This is so because such correlations are the basis for conservation of the local species both on-farms and in the wild habitats.

4.1.6. Total Seed Number. The total number of T. indica seeds per fruit documented in this study ranges from 1 to 17. Seeds are the foundation for any tree multiplication programme. The seeds are important to plants because they ensure that the gene pool continues to the next generation. Seed numbers can be emphasized when many seeds are preferred for breeding programme as well as nutritional (proximate, mineral, and physicochemical) properties. The highest number of seeds per fruit (17) recorded in this study is more than those reported in other studies carried out elsewhere, such as $[1,2]$. The high number of seeds indicates how important the samples are for nutritional product development as well as developing improved T. indica cultivars for specific environments (and possibly agroecological zones) in Uganda.

The high number of seeds revealed in this study could be related to agroclimatic factors, soil conditions, farming systems, and geological formations, which differ across the various agroecological zones in Uganda. Soils in Eastern agroecological zone are made of mainly Serere and Amuria catena, Metu complex, and Usuk series [17]. Many are of ferralitic type (sandy sediments and sandy loams) which are well drained, friable, and exhibiting low cation exchange capacity and high anion absorptive capacity. This could have been responsible for the seed numbers observed in this study. Also, Raddad [39] documented that clay and sand types usually have effects on the seed number and seed weight of Acacia senegal. In addition, the study documented a positive and strong correlation between the seed number and seed mass $(\mathrm{R}=0.79)$, fruit mass $(\mathrm{R}=0.63)$, fruit length $(\mathrm{R}=0.58)$, and pulp mass $(\mathrm{R}=0.56)$, which means many seeds in a long fruit pod produce heavier seed mass and heavy fruits and pulp, which is more preferred by the local communities in the study areas and will go a long way in tree development.

4.1.7. Total Seed Mass. The amount of total seed mass per fruit is higher (0.18-17.15 g) in Lake Victoria Crescent zone than in West Nile and Eastern agroecological zones, respectively. In this study, the total seed mass per fruit is higher than that reported by Abraham et al. [23] while Bilcke et al. [22] reported higher values than values reported in our study. However higher values were reported by Mkwezalamba et al. [28] and Orsanic et al. [31] for Sclerocarya birrea (A. Rich.) Hochst and Sorbus torminalis L. Crantz, respectively. The findings of this study corroborate with results obtained by Aline et al. [40] who documented higher average values of length, width, thickness, and seed fresh mass among Prunus persica cultivars. Mkwezalamba et al. [28] and Kadu et al. [41] also reported that bigger seeds are the best for selection for early seedling growth and development.

It was possible to deduce that the bigger the fruit fresh mass is, the bigger the seed mass will be. Seeds with bigger mass present better germination capacity, standardization, and seedling emergence [42]. Such characteristics are useful to help the selection of new genotypes to be used as rootstocks, which, in addition to the standardization of fruit lots with higher fresh mass, allows obtaining seed lots with higher mass and with maximum germination power, an implication for the reduction of management and improving the homogeneity of seedling lots. This is so because agroecological zone with a greater number of seeds per fruits (fresh and dry weights) tends to have high pungency and seeds and heavier mass could have more food reserves. Although large food reserves could prolong seed viability and seed storage and enhance seed germination and vigorous seedlings growth, more studies are still required to find out whether larger seed (in this study) would produce high quality seedlings, nutritional values, and taste differently compared to lighter seed of T. indica in the different zone.

4.2. Agroecological Zones, Land Uses, and T. indica Morphological Variations. In plants, the phenotypic variation is generally a response to differences in climatic conditions, which reflects either adaptive evolution or phenotypic plasticity, or a combination of the two [43]. Many studies that documented phenotypic changes in natural populations attributed them to climate change. In addition, Parmesan [44] and 
Chen et al. [45] have examined and compared intraspecific phenotypic variation across the geographic ranges of selected species. Within the same agroecological zone, we reported significant differences in land use types (on-farm and wild) and altitudes where the T. indica individuals grow, which could have also been the possible cause of the obtained differences. Maranz and Wiesman [46] reported that important variability in Vitellaria paradoxa fruit and seed sizes in relation to climate gradient was found throughout the entire sub-Saharan Africa zone located at the northern part of the equator.

In this study, sampled T. indica fruits were from altitudes that ranged from 593 to 1,096 masl (1,050-1,093; 1,030-1,096; and 593-997 masl for Lake Victoria Crescent and Eastern and West Nile zones, respectively). This shows that, even within the same agroecological zone, there are differences in altitude where T. indica grows. Similar findings were reported earlier by Mayavel et al. [21] who documented T. indica 21 genotypes of red tamarind at Tamil Nadu between elevations 3-773 masl while Orwa et al. [30] found out that T. indica trees usually grow at altitude between 0 and 1,500 masl and mean annual rainfall from 350 to $2,700 \mathrm{~mm}$. In addition to altitude, $T$. indica grows at different soils (productivity and fertility) and soil types, topography, vegetation cover, climate (such as rainfall totals and distribution), geological formation, rainfall, and farming systems or practices [3-5].

The observed differences in T. indica morphological trait characteristics probably indicate the influence of agroecological zones, environmental factors, climatic factors (such as elevation, topography, effects of geography, surface of the earth, climate change over time, and prevailing wind), and land use types on the T. indica trees, which differs in these zones and concurs with [1] that reported the substantial effects of the environmental and land use factors. A study by Fatima et al. [8] indicated that parameters that affect growth, development, and health condition of a tree range from physical factors (climate, soils, water balance, and topography) and biological factors (diseases and pests) to land use types. It was, however, not possible to state which of these factors and others have had a greater effect in producing these variations. Because the flowers of $T$. indica are predominantly openpollinated and usually nonuniform, with wild land use trees probably having more pollinators than those on-farms, great variations in a wide range of characteristics such as seedlings, tree size and structure, leaf and fruit form, age to bearing, and fruit quality are bound to be exhibited. This could be the reason why there were significantly bigger and heavier fruits in the wild than on-farms.

\subsection{Correlation Relationships among T. indica Morpholog-} ical Traits. The correlation and path analysis studies are important in fruit crops like tamarind, mango, and citrus [21], where its quantity and quality traits are important in improvement programme. Correlation studies between traits of a crop are of interest to the breeders in planning the hybridization programme and evaluating the individual plants in segregating populations [47]. Understanding the existing correlations between fruit and seed characteristics allows relating the behaviour of a variable through analysis of the other, even if it does not give an exact position of the relative importance of direct and indirect effects of the various characters on yield [47]. Together it will provide knowledge on interrelationships and relative contribution of independent characters on dependent variables which enables a tree breeder to apply suitable selection procedures in tree improvement programme. The knowledge on nature and magnitude of interrelationship among yield and its contributing factor is mandatory for the simultaneous improvement of characters and yield [21]. Such correlation studies can be used in indirect selection of plus trees. Selection can be used on most morphological characteristics to select traits of interest which are difficult to assess [21]

All fruits and seeds morphological traits presented significant and uphill positive strong correlations. Similar results were reported by Dresch et al. [34] who observed a positive and moderate correlation between fruit width with seed thickness, and similar correlation types were documented [28] for Sclerocarya birrea fruits. Correlations witnessed among all traits reported are important because they show that all these traits can be used indirectly to select plus trees for yield per tree and the development of various nutritious components of the species. On the other hand, the weak or low positive relationships that exist in some characteristics could probably mean that indirect selection may not be possible. Association of characteristics determined by correlation may not provide an exact picture of the relative significance of direct and indirect influence of each of the yield components towards yield [47]. Khan et al. [47] reported that the phenotypic and genotypic variations of the yield components are considerably high in some species such as pointed gourd, which points to the possibility of developing a variety with high yield. It is certainly the case that many factors contribute to the relative amounts of variation observed among populations of the same species.

The numbers of fruits and seeds are important biological properties which influence the ability to generatively propagate particular tree species. A positive and quite strong correlation between the number of seeds and seed mass $(\mathrm{R}=0.78)$ was obtained, indicating that the seeds mass per plant would increase with the increase in seed number. Even then, the low number of seeds per fruit can be explained by low density of T. indica trees in the studied populations and by small isolated populations with low gene flow between the neighbouring populations as well as by the decrease in gene numbers. Inadequate silvicultural practices of T. indica trees especially in the wild population also make the T. indica trees grow in stressful ecological conditions (such as frequent fires), which can result in reduced fertilization. T. indica's bisexual flowers exhibit protogynous dichogamy, with flowering occurring in dry season where there is both self- and cross-pollination but the latter is much more effective. However, these processes are affected by these anthropogenic activities.

\section{Conclusion}

There were significant differences in the morphological traits of $T$. indica fruits and seeds across the agroecological zones of Uganda. Lake Victoria Crescent agroecological zone had 
higher fruit morphological traits values than other zones. T. indica traits from wild and on-farm land use types were superior in fruits and seed trait values, respectively. Many seeds per fruit, up to 17, were recorded in Uganda's Eastern agroecological zone than those recorded elsewhere. All fruits and seed morphological traits showed variabilities within the agroecological zones and land use types. Strong significant uphill positive linear correlations between all morphological traits $(\mathrm{P} \leq 0.05)$ were observed, with the strongest relationships being between seed mass and seed number $(\mathrm{R}=0.78)$, total fruit mass and fruit length $(\mathrm{R}=0.73)$, pulp mass and total fruit mass $(\mathrm{R}=0.72)$, and seed mass and total fruit mass $(\mathrm{R}=0.72)$. The dispersion/variation and correlated relationships suggest that all the studied morphological traits can be used for selection of plus trees for tree breeding improvement. This study also suggests that it may not be challenging for the tree breeding improvement to simultaneously increase $T$. indica fruits and seed traits in the same breeding population and will not require separate ideotypes for the traits. The observed variations are probably attributed to influence of agroecological zones factors, environmental factors, climate, land use types, and farming systems, a reflection of $T$. indica species adaptation to different conditions showing high genetic and phenotypic differences to be exploited. This study represents the first quantitative evaluation of $T$. indica morphological traits variation and should form the basis to guide the indirect selection of plus tree species for valuable nutritional requirements in both wild and on-farm land uses. The study findings were based on data collected in a single dry season of the trees' lifespan which possibly possesses uncertainty in variations among agroecological zones and land use types whose uses keep changing. In addition, the exact start of dry season period which is slightly different from one zone to another does vary due to climate change. There is therefore a need to carry out more studies to fully understand variations which may occur due to seasonality.

\section{Data Availability}

No data were used to support this study.

\section{Conflicts of Interest}

The authors declare that there are no conflicts of interest in any form regarding the publication of this paper.

\section{Acknowledgments}

We are most grateful for having received financial support from Norwegian Agency for Development Cooperation (NORAD) through Makerere University. The authors are also indebted to the field assistants, laboratory staff, friends, and the farmers whose fields were visited during data collection that made the compilation leading to the development of this manuscript possible.

\section{Supplementary Materials}

The raw data used in the production of this manuscript is attached here as a supplementary file. Full and detailed descriptions of how these data were collected, analysed, and presented in this manuscript appear in Part 2, i.e., pages 4-8. (Supplementary Materials)

\section{References}

[1] K. El-Siddig, H. P. M. Gunasena, B. A. Prasad et al., Tamarind (Tamarindus indica L.). Fruits for the Future 1, International Centre for Underutilised Crops, Southampton, UK, 2006.

[2] E. M. Yahia and N. K. E. Salih, Tamarind (Tamarindus indicaL.), Woodhead Publishing Limited, 2011.

[3] J. Okello, J. B. L. Okullo, G. Eilu, P. Nyeko, and J. Obua, "Mineral composition of Tamarindus indica LINN. (tamarind) pulp and seeds from different agro-ecological zones of Uganda," Journal of Food Science and Nutrition, vol. 5, no. 5, pp. 959-966, 2017.

[4] J. Okello, J. B. L. Okullo, G. Eilu, P. Nyeko, and J. Obua, "Physicochemical Composition of Tamarindus indica LINN. (Tamarind) in the Agro-Ecological Zones of Uganda," Journal of Food Science and Nutrition, vol. 6, no. 5, pp. 1179-1189, 2018.

[5] J. Okello, J. B. L. Okullo, G. Eilu, P. Nyeko, and J. Obua, "Proximate Composition of Wild and On-Farm Tamarindus indica LINN. Fruits in The Agro-Ecological Zones of Uganda," Journal of Food Processing and Technology, 2018.

[6] J. Gebauer, K. El-Siddig, and G. Ebert, "The Potential of Underutilized Fruit Trees in Central Sudan," in Proceedings of the International Agricultural Research for Development, Deutscher Tropentag, Witzenhausen, 2002.

[7] C. Okwu, E. G. Oboho, E. K. Asaah, E. S. Osazuwa, S. O. Igberaese, and Z. Tchoundjeu, "Phenotypic Variations in Fruits and Seed Traits of Chrysophyllum albidum in three Agroecological Zones in Nigeria,' Scientific Research Journal (SCIRJ, vol. 5, no. 10, pp. 39-50, 2017.

[8] F. El Ayadi, F. Msanda, F. Baniaameur, and A. El Mousadik, "Morphological and Shape Fruits Variability of Acacia tortilis ssp. Raddiana (Savi) Brenan in South Morocco," International Journal of Plant Breeding and Genetics, vol. 6, no. 4, pp. 151-167, 2012.

[9] C. R. Elevitch and H. I. Manner, Traditional Tree Initiative Species Profiles for Pacific Island Agroforestry (http//www .traditionaltree.org), Artocarpus heterophyllus, jackfruit, 2006.

[10] N. Kaushik, S. Kumar, K. Kumar, R. S. Beniwal, N. Kaushik, and S. Roy, "Genetic variability and association studies in pod and seed traits of Pongamia pinnata (L.) Pierre in Haryana, India," Genetic Resources and Crop Evolution, vol. 54, no. 8, pp. 18271832, 2007.

[11] FAO, Food and Agriculture Organization of The United Nations, Forest Genetic Resources, Rome, Italy, 2004, http://www.fao .org/3/a-y5901e.pdf.

[12] J. Lakor, G. Elepu, M. J. Buyinza, and P. Nyeko, "Analysis of Tamarindus (Tamarindus indica L.) Value Chain in Uganda: Identification of Opportunities and Constraints to Its Commercialization and Domestication," Journal of Agriculture and Environmental Sciences, vol. 5, no. 1, pp. 101-112, 2016.

[13] M. Masette, A. Candia, and A. Grace Ocheng, "The commercial viability of Tamarind (Tamarindus indica L) fruit based products for improved incomes among farmers in Northern and Eastern Uganda," African Journal of Food Science and Technology, vol. 06, no. 06, pp. 167-176, 2015. 
[14] P. Nyadoi, P. J. B. L. Okori, J. Okullo et al., “Tamarinds' (Tamarindus indica L.) niche tree species diversity characterisation reveals conservation needs and strategies," International Journal of Biodiversity and Conservation, vol. 1, no. 4, pp. 151176, 2009.

[15] NEMA, National Environment Management Authority, State of the Environment Report for Uganda 2006-2007, Kampala, Uganda, 2007.

[16] GoU, Government of The Republic of Uganda, Increasing Incomes through Exports: A Plan for Zonal Agricultural Production, Agroprocessing and Marketing, Kampala, Uganda, 2004.

[17] UDIH, Uganda Districts Information Handbook, Expanded Edition 2007 - 2008, Fountain Publishers, Kampala, Uganda, 2007.

[18] NEMA, National Environment Management Authority, District State of Environment Report for Moyo District, Moyo, Uganda, 2004.

[19] NEMA, National Environment Management Authority, District State of Environment Report for Nakasongola District, Uganda, 2004.

[20] ISTA (International Seed Testing Association), "International Rules for Seed Testing: Rules 1996," Seed Science and Technology, vol. 24, pp. 1-335, 1996.

[21] A. Mayavel, B. Nagarajan, K. Muthuraj, A. Nicodemus, and R. Prabhu, "Correlation and Path Coefficient Analysis of Selected Red Tamarind (Tamarindus indica var rhodocarpha) Genetic Resources,' International Journal of Current Microbiology and Applied Sciences, vol. 7, no. 04, pp. 794-802, 2018.

[22] N. Van den Bilcke, K. Alaerts, S. Ghaffaripour, D. J. Simbo, and R. Samson, "Physico-chemical properties of tamarind (Tamarindus indica L.) fruits from Mali: Selection of elite trees for domestication," Genetic Resources and Crop Evolution, vol. 61, no. 2, pp. 537-553, 2014.

[23] Z. Abraham, S. K. Malik, G. E. Rao, S. L. Narayanan, and S. Biju, "Collection and characterisation of Malabar tamarind [Garcinia cambogia (Gaertn.) Desr.]," Genetic Resources and Crop Evolution, vol. 53, no. 2, pp. 401-406, 2006.

[24] P. Soloviev, T. D. Niang, A. Gaye, and A. Totte, "Variability of fruit physicochemical characters for three harvested woody species in Senegal: Adansonia digitata, Balanites aegyptiaca and Tamarindus," Fruits, vol. 59, no. 2, pp. 109-119, 2004.

[25] B. Fandohan, A. E. Assogbadjo, R. Glèlè Kakaï, T. Kyndt, and B. Sinsin, "Quantitative morphological descriptors confirm traditionally classified morphotypes of Tamarindus indica L. fruits," Genetic Resources and Crop Evolution, vol. 58, no. 2, pp. 299-309, 2011.

[26] M. Ji, J. Deng, B. Yao et al., "Ecogeographical variation of 12 morphological traits within Pinus tabulaeformis: the effects of environmental factors and demographic histories," Journal of Plant Ecology, vol. 10, no. 2, pp. 386-396, 2017.

[27] S. Dadegnon, C. Gbemavo, C. Ouinsavi, and N. Sokpon, "Morphological Variation and Ecological Structure of Chrysophyllum albidum G. Don," International Journal of Plant \& Soil Science, vol. 5, no. 1, pp. 25-39, 2015.

[28] I. Mkwezalamba, C. R. Y. Munthali, and E. Missanjo, "Phenotypic Variation in Fruit Morphology among Provenances of Sclerocarya birrea (A. Rich.) Hochst," Journal of Forestry Research, vol. 2015, Article ID 735418, 8 pages, 2015.

[29] T. Abasse, J. C. Weber, B. Katkore, M. Boureima, M. Larwanou, and A. Kalinganire, "Morphological variation in Balanites aegyptiaca fruits and seeds within and among parkland agroforests in eastern Niger," Agroforestry Systems, vol. 81, no. 1, pp. 57-66, 2011.
[30] C. Orwa, A. Mutua, R. Kindt, R. Jamnadass, and S. Anthony, Agroforestree Database: a tree reference and selection guide version 4.0, 2009, http://www.worldagroforestry.org/sites/treedbs/ treedatabases.asp/.

[31] M. Oršanić, D. Drvodelić, T. Jemrić, I. Anić, and S. Mikac, "Variability of morphological and biological characteristics of Wild Service Tree (Sorbus torminalis (L.) Crantz) fruits and seeds from different altitudes," Periodicum biologorum, vol. 111, no. 4, pp. 495-504, 2009.

[32] R. L. Jarret and T. Berke, "Variation for fruit morphological characteristics in a Capsicum chinense Jacq. germplasm collection," HortScience, vol. 43, no. 6, pp. 1694-1697, 2008.

[33] M. A. Santos, L. F. Braga, R. M. Rondon Neto, and A. M. Sorato, "Aspectos morfológicos e fisiológicos da germinação e morfometria de frutos e sementes de swartzia recurva poeep (fabaceae)," Ciencia \& Natura, vol. 37, no. 3, pp. 34-54, 2015.

[34] D. M. Dresch, S. d. Scalon, T. E. Masetto, and M. d. Vieira, "Germinação e vigor de sementes de gabiroba em função do tamanho do fruto e semente," Pesquisa Agropecuária Tropical, vol. 43, no. 3, pp. 262-271, 2013.

[35] R. M. Silva, R. d. Ribeiro, D. J. Coutinho, S. I. Silva, and M. I. Gallão, "Caracterização de frutos, sementes, plântulas e germinação de Jeniparana," Revista Ceres, vol. 61, no. 5, pp. 746751, 2014.

[36] S. A. Felizardo, A. D. Freitas, N. D. Marques, and D. A. Bezerra, "Características biométricas de frutos e sementes de Oenocarpus bataua Mart. com procedência em Almeirim, Pará," Revista Verde de Agroecologia e Desenvolvimento Sustentável, vol. 10, no. 2, p. 09, 2015.

[37] B. İmrak, A. B. Küden, E. Tanriver, and E. Kafkas, "Volatile and some fruit quality characteristics of new promising peach genotypes," Acta Scientiarum Polonorum, Hortorum Cultus, vol. 14, no. 2, pp. 3-12, 2015.

[38] J. A. Barrera, M. S. Hernández, L. M. Melgarejo, O. Martínez, and J. P. Fernández-Trujillo, "Physiological behavior and quality traits during fruit growth and ripening of four Amazonic hot pepper accessions," Journal of the Science of Food and Agriculture, vol. 88, no. 5, pp. 847-857, 2008.

[39] E. A. Y. Raddad, "Ecophysiological and genetic variation in seedling traits and in first-year field performance of eight Acacia senegal provenances in the Blue Nile, Sudan," New Forests, vol. 34, no. 3, pp. 207-222, 2007.

[40] A. das Graças Souza, O. J. Smiderle, V. M. Spinelli, R. O. de Souza, and V. J. Bianchi, "Correlation of biometrical characteristics of fruit and seed with twinning and vigor of Prunus persica rootstocks," Journal of Seed Science, vol. 38, no. 4, pp. 322-328, 2016.

[41] C. A. C. Kadu, M. Imbuga, R. Jamnadass, and I. K. Dawson, "Genetic management of indigenous fruit trees in southern Africa: a case study of Sclerocarya birrea based on nuclear and chloroplast variation," South African Journal of Botany, vol. 72, no. 3, pp. 421-427, 2006.

[42] R. C. Colombo, V. Favetta, L. Y. Yamamoto et al., "Biometric description of fruits and seeds, germination and imbibition pattern of desert rose [Adenium obesum (Forssk.), Roem. \& Schult.]," Journal of Seed Science, vol. 37, no. 4, pp. 206-213, 2015.

[43] J. Merilä and A. P. Hendry, "Climate change, adaptation, and phenotypic plasticity: The problem and the evidence," Evolutionary Applications, vol. 7, no. 1, pp. 1-14, 2014.

[44] C. Parmesan, "Ecological and evolutionary responses to recent climate change," Annual Review of Ecology, Evolution and Systematics, vol. 37, pp. 637-669, 2006. 
[45] I.-C. Chen, J. K. Hill, R. Ohlemüller, D. B. Roy, and C. D. Thomas, "Rapid range shifts of species associated with high levels of climate warming," Science, vol. 333, no. 6045, pp. 10241026, 2011.

[46] S. Maranz and Z. Wiesman, "Evidence for indigenous selection and distribution of the shea tree, Vitellaria paradoxa and its potential significance to prevailing parkland savanna tree patterns in sub-Saharan Africa north of the equator," Journal of Biogeography, vol. 30, no. 10, pp. 1505-1516, 2003.

[47] A. S. M. M. R. Khan, M. Y. Kabir, and M. M. Alam, "Variability, Correlation Path Analysis of Yield and Yield Components of Pointed Gourd," Journal of Agriculture and Rural Development, vol. 7, no. (1\&2), pp. 93-98, 2009. 

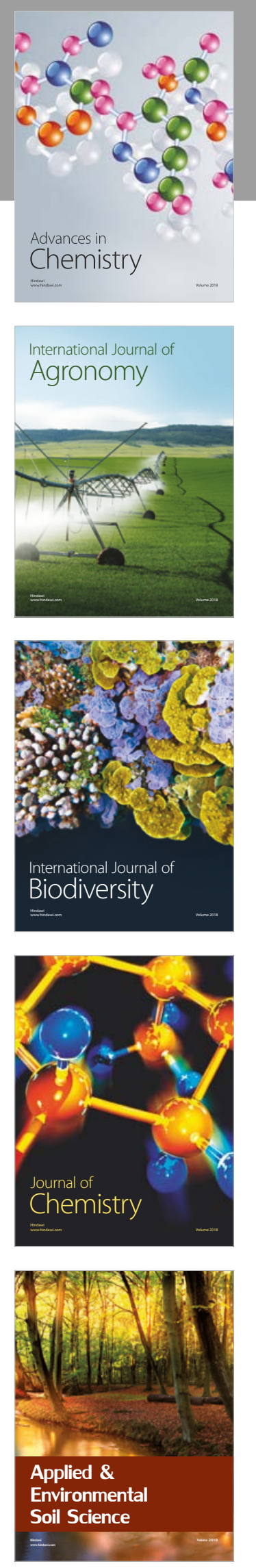

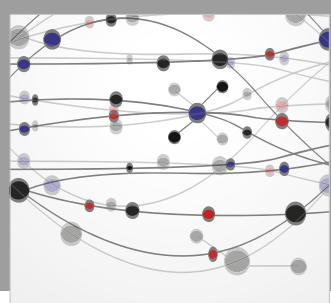

The Scientific World Journal

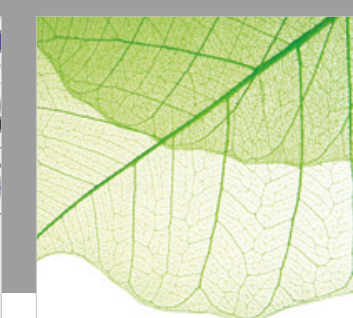

Journal of Botany

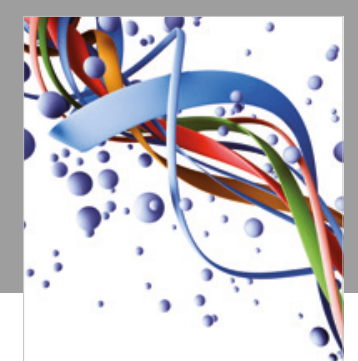

Scientifica

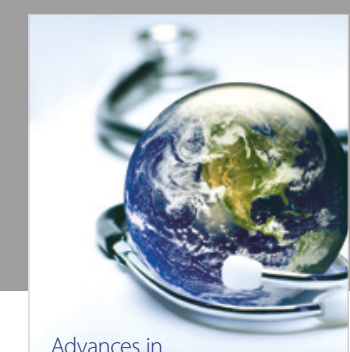

Public Health

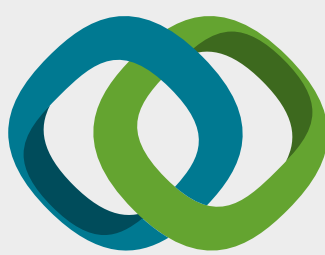

Hindawi

Submit your manuscripts at

www.hindawi.com
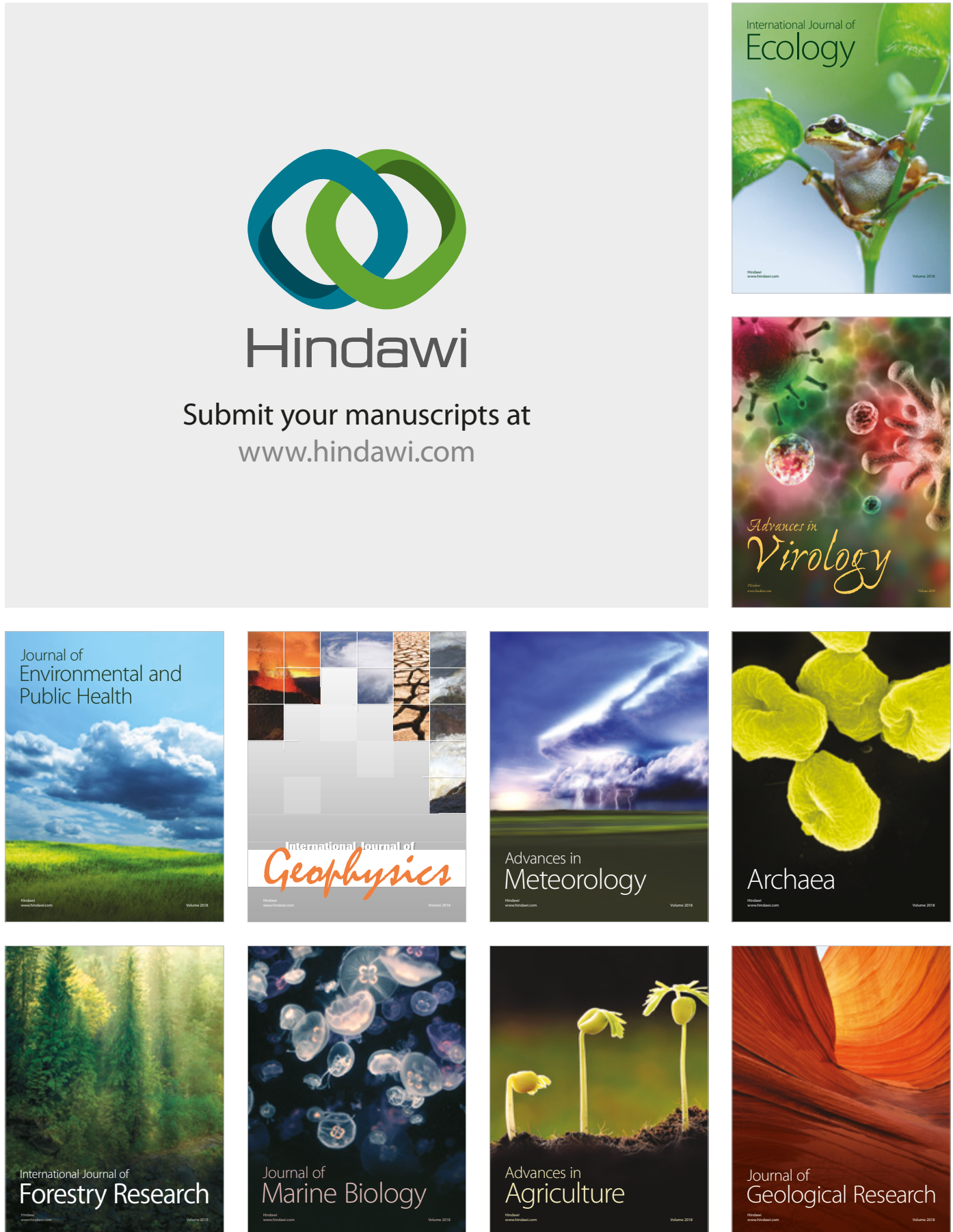

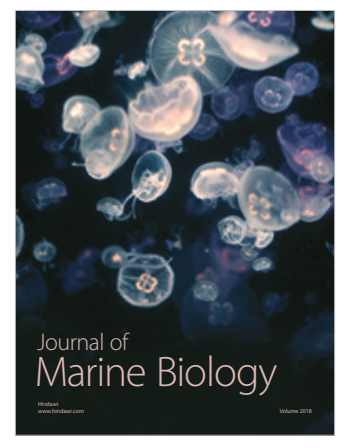

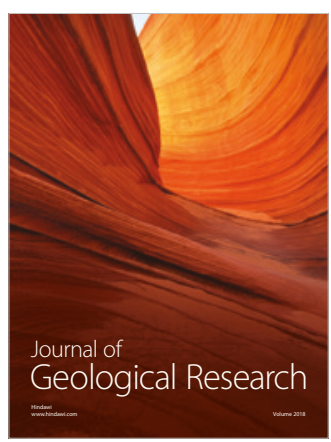

